\title{
Attitudes, Platitudes and the Collegiate Sports Arms Race: Unsustainable Spending and Its Consequences for Olympic and Women's Sports
}

\author{
Nancy Hogshead-Makar \\ Florida Coastal School of Law
}

Good afternoon. First, I'd like to applaud the authors of this paper, Amy Perko, R. Gerald Turner and Rick Hessel, as well as the work of the Knight Commission. Their collective research and analysis in A Sustainable Model? University Presidents Assess the Costs and Financing of Intercollegiate Athletics ("A Sustainable Model") sheds new light on the perspectives of college and university presidents regarding the sustainability of the financial structure of intercollegiate athletics. Since 1991, the Knight Commission has called upon college and university presidents for leadership in setting the proper tone about the value of sports for college students and the educational mission of athletics (Knight Foundation, 1991). The Knight Commission's most recent work, however, demonstrates some flaws by relying on past strategies when tackling the most recent challenges. The underlying economic structure of intercollegiate athletics must be changed to reign in the excessive expenditures and the commercialization of sport.

Let me explain my background and experience. I've now been involved with legal and policy issues surrounding women in athletics for over 25 years. Starting as a college intern at the Women's Sports Foundation ("WSF") in 1985, I eventually served as its third president from 1992-94, and I was the WSF's Legal Advisor for seven years and I am currently the Senior Director of Advocacy. When I first started as an intern in San Francisco, it seemed to me and many others in intercollegiate athletics that collegiate spending on college athletics in general, and football in particular, was on an unsustainable trajectory. In 1985, the average NCAA Division I men's budget was $\$ 6,158,000$, while the average women's budget was just $\$ 799,000$. At that time, it seemed appalling that only two men's sports, football and men's basketball, could consume $49 \%$ of the athletics budget (Fulks, 2002). ${ }^{1}$ Since then, the problems have multiplied many times over, as greater concentrations of resources have continued to be funneled into two men's sports, ostensibly without constraint. (Orszag \& Orszag, 2005) In 2005, the average NCAA Division I men's budget was $\$ 15,200,000$, while the average women's budget was $60 \%$ less, around just $\$ 6,000,000$ (Fulks, 2008). ${ }^{2}$ Football and men's basketball now consume $76 \%$ of athletics budget. After correcting for inflation, overall spending on athletics has 
increased by roughly $7 \%$ annually over the past 10 years, over four times the rate of the general educational budget (Fulks, 2008; Knight Commission, College Sports 101.). There is considerable reason to suspect that even these numbers discount the losses sustained by FBS. Capital replacement costs, as just one example, are not included in DIA athletic department expenses, and have been estimated to average \$24 million per year (Orszag \& Orszag, 2005).

Unfortunately, not much of this new spending is going toward increasing sports participation opportunities at D1 institutions. Instead, the bulk of the increased expenditures are funneled into two existing teams, football and men's basketball (Cheslock, 2008; Kretchmar, 2009). This overall spending on athletics perhaps would not be a cause of alarm if revenue increases were commensurate, so that there were enough resources for athletics departments generally. However, the latest reports demonstrate that roughly $80 \%$ of the FBS programs averaged a net operating deficit of nearly $\$ 10$ million (Fulks, 2008). Not only is there not enough money for to sustain current sports at D1 institutions; money is being funneled from the academic side of institutions. A Sustainable Model reveals presidents are not up to the challenge of changing the underlying economic structure of intercollegiate athletics. The consequences of continuing along the current path have obvious implications for women's sports_-indeed, for all Olympic sports. ${ }^{3}$

\section{Many College Presidents Considered Current Spending To Be Sustainable at Their Institution-But Only If Other Sports Were Eliminated and/or Fewer Resources Were Provided To Remaining Sports}

The results in A Sustainable Model may seem divorced from women's and other Olympic sports participation. After all, the survey did not address women's athletics, Title IX (Education Amendments of 1972), or Olympic sports directly. Nonetheless, the data provide cause for serious concerns for all other sports participants for many reasons, three of which I will highlight.

First, many presidents framed the question of economic viability only as it related to spending trends of two men's sports, football and basketball. For example, two-thirds of all presidents expressed confidence that spending was sustainable at their own institution, and three quarters $(76 \%)$ of equity presidents ${ }^{4}$ thought intercollegiate financing was sustainable (Perko \& Turner, 2010). At the same time, almost half of all college presidents (48\%) thought current economics would require reductions in the number of sports at their schools (Perko \& Turner). In other words, the very context and meaning of "sustainable spending" was specific to the growing financial requirements of football and men's basketball, not to athletics departments as a whole. Troubling consequences for women and Olympic sports exist when such a large percentage of college presidents structure their answer to the question posed in terms of continuously finding additional financial sources for only football and men's basketball, not on "sustainable spending" for the athletic experiences of the whole department. Inevitably, I know from experience that any losses to men's Olympic sports will be blamed on women and Title IX (HogsheadMakar \& Zimbalist, 2007). ${ }^{5}$ Yet the responses of presidents fail to acknowledge the accuracy of the frequent statement of Christine Grant, former Women's Athletics 
Director and 2007 winner of the NCAA's President's Gerald R. Ford Award ${ }^{6}$ that the problem is “the insatiable appetite for men's basketball and football are leading some colleges to overspend and eventually drop men's Olympic sports (e.g., swimming, wrestling, track) as a way to balance the budget" (Powers, 2007). In the 2007 Participation Report, Division III and II were adding sports for men at a brisk pace between 1988-2007; 346 men's teams and 142 men's teams respectively. Only in Division I was there a net loss of 277 men's teams.

Second, in addition to dropping Olympic sports at these institutions, two-thirds of presidents were supportive of shortening seasons with fewer competitions for all other sports as a way to contain costs (Perko \& Turner, 2010). The proposition is akin to shortening the academic calendar year for all but two departments, and not because the decision enriched the educational experience of the students with shorter academic years. Cuts are often required in recessionary times, yet unless cuts are done in an equitable manner, they may violate Title IX and other gender equity laws. At public institutions, such inequitable cuts may also violate the Equal Protection clause of the United States Constitution (Fourteenth Amendment). ${ }^{7}$

Let me relate a personal story. In 2009, the Florida High School Athletic Association ("FHSAA") tried the same inequitable budget-cutting tactic with abysmal consequences. On April 27th, the FHSAA board of directors voted to cut regular-season athletic schedules by $20 \%$ for varsity contests and $40 \%$ for junior varsity contests, while exempting football and competitive cheerleading (Thomas, 2009). By excluding football, $29 \%$ of boys' competitions were unaffected versus just $5 \%$ of girls' competitions (Thomas, 2009). ${ }^{8}$

During public prelitigation discussions, the problems of a sports association mandating equal numbers of cuts for specific male and female teams became obvious. Different schools sponsored different sports teams of very different sizes for males and females, making top-down association-mandated cuts to specific sports impossible. For example, schools without football teams would have no girls' competitive schedules restored. Some girls' teams would have played $20 \%$ more games than other girls' teams, making it difficult to determine which team qualified for postseason competitions.

After numerous attempts to resolve the conflict without litigation failed, a team of attorneys filed a federal lawsuit, including Wayne Hogan, Leslie Goller from the law firm of Terrell Hogan, and David Baron from Baron and Herskowitz, as well as myself (Hackney, 2009). Shortly thereafter, the Department of Justice filed an amicus brief on behalf of the plaintiffs, also asserting that the gender-inequitable cuts violated Title IX (U.S. Department of Justice website). The case was settled by restoring competitive schedules to all sports, not just the girls' sports (FHSAA website). The litigation cost the FHSAA about $\$ 100,000$ in total, including plaintiffs' and defense costs and fees (Barnett, 2009). It was a wasteful and unnecessary expense, particularly given the many attempts to get the FHSAA to agree to the same remedies the law would inevitably impose upon it in the end.

The experience of the FHSAA is instructive for the NCAA and the presidents, as they attempt to cut expenses in recessionary times. Given that two-thirds of equity presidents favor cutting into Olympic sports seasons and competitive schedules, A Sustainable Model reveals how the relentless search for money for football and men's basketball could violate gender equity laws as well as unjustifiably deprive all other sports programs of competition opportunities. 
Third, three-quarters of presidents supported reducing the level of financial commitment required for FBS membership (Perko \& Turner, 2010). The survey did not specify which NCAA By-laws they would advocate modifying, but given presidents' earlier responses, this proposal could be cause for concern when many of the FBS membership requirements protect all other sports, ensuring a well-rounded athletics program and the financial commitment to all sports. Some membership requirements ensure that collegiate athletic departments do not wither to just a handful of sports. For example, NCAA Bylaw 20.9 requires Division I FBS schools to sponsor at least 16 sports (NCAA, 2007). NCAA Bylaw 20.9.7.4-(b) requires FBS members to provide an average of at least 200 athletics scholarships or expend at least four million dollars on athletic scholarships. ${ }^{9}$ Minimum numbers of teams and scholarships protect the entire department from further cuts to Olympic sports.

Without the combination of federal law requiring equity in educational opportunities for men and women and these specific FBS membership requirements, a further concentration of resources into the two men's sports could occur. What is most revealing in presidents' responses in A Sustainable Model is that a majority of presidents are considering taking resources from Olympic sports, the so-called "have-nots" from within the athletic departments, rather than identifying systemic solutions for the continual concentration of resources into two men's sports.

\section{Exponential Growth for Two Men's Sports Heightens Gender Equity Tensions Within Athletics Departments for Employees}

A Sustainable Model reveals the dominant belief system in the importance of continued and increased funding for football and men's basketball. If the dominant athletic departmental culture is one that is in lock-step with the flawed model, which requires schools to pour more and more resources into football and men's basketball, since wins here are regarded as imperative to the success of the overall department as an enterprise, it becomes very difficult for women to function in athletics programs that are ostensibly education-based opportunities. While the NCAA has instituted programs to mentor women into collegiate athletics career choices and has published laudable materials on negotiating the work and life balance (Lange, 2008), opportunities for women to coach women's teams are at an all time low, 42.6\% (Acosta \& Carpenter, 2008). Given that less than three percent of males are coached by female head coaches, almost $80 \%$ of all head coaches are male. Gender equity coaches or administrator- advocates who strive for equality within their department, who insist on faithfully fulfilling the institution's gender equity plans, who advocate for the expansion of women's programs in response to the growing demand for women's sports, are seen as "traitors", as disloyal to an institution's overall program, or as antithetical to men's Olympic sports. It puts tremendous internal pressures on professional choices. Gender equity advocates bite their tongues, seeing themselves as unable to advocate on behalf of their athletes while still remaining employed in collegiate athletics.

The overt presumption, that two men's sports are more important than women's sports, may have sway within some intercollegiate athletic departments. The dollars spent certainly reflect this presumption. Over the past decade, the $7 \%$ annual growth 
rate of athletics departments has translated into an additional $\$ 2,450,000$ for football per school, while increasing the expenditures in women's sports by approximately $\$ 135,000$ per team (Cheslock, 2008). But the presumption of male superiority for two men's sports is easily rebutted in education; indeed, it is a legally dangerous one that plays very poorly to judges and juries who are bound to enforce the law.

Since the ruling of the United States Supreme Court in Jackson v. Birmingham (2005) affirming a cause of action for retaliation under Title IX, numerous cases have been brought by women working in collegiate athletics, alleging their department retaliated against them for their advocacy for the women athletes. Results reflect the national aspiration for equality under the law is alive and well, as further reflected in surveys such as the Mellman Group Public Opinion survey. In the poll, more than "eight in ten voters $(82 \%)$ support Title IX, while only $15 \%$ oppose it. Moreover, support for the law is intense with nearly two-thirds (65\%) strongly supporting the law and fewer than one in ten (9\%) strongly opposing it. Support for Title IX is both deep and wide, crossing the political spectrum. Majorities of Democrats ( $86 \%$ favor, $11 \%$ oppose), independents ( $78 \%$ favor, $15 \%$ oppose) and Republicans (78\% favor, $19 \%$ oppose) favor the law. Majorities also support the law across gender and age, with nearly united support from women (86\%) and men $(77 \%)$. Voters in every part of the country favor the law by wide margins." (Mellman, 2007) Juries pulled from the general public and not from within athletics departments who are shown unfair treatment toward women athletes and employees based on this presumption often send strong signals in their verdicts. Below are just a few of the more recent cases.

- California Berkley paid \$3.5 million to its former women’s swimming coach and athletics administrator Karen Moe Humphreys, who filed a discrimination and retaliation suit alleging she was fired because she complained about treatment of women in the athletics department (Steeg, 2008).

- Fresno State faced retaliation claims from three of its former Athletics Department employees. Lindy Vivas, Fresno State's former women's volleyball coach, was awarded $\$ 5.85$ million by a jury, later reduced to $\$ 4.52$ million plus $\$ 660,000$ in legal fees. Stacy Johnson-Klein, a former women's basketball coach, was awarded \$19.1 million, the largest in history for any kind of discrimination against any kind of institution. The verdict was later was reduced to \$6.6 million, plus \$2.5 million in legal fees. Fresno State settled with Diane Milutinovich, Fresno's former associate athletics director, for $\$ 3.5$ million (Steeg, 2008).

- Florida Gulf Coast University paid \$3.4 million to two former women's coaches, Jayne Flood and Holly Vaughn, to settle a 2008 lawsuit alleging retaliating against the women after they voiced concerns about gender inequity in the school's athletic programs (Public Justice Foundation, 2008).

To put this of jury-hostility into context, a death from medical malpractice averages just over one million dollars in final verdicts (Gosselar, Lincoln and Arkush, 2009; Kelso \& Kelso, 1999). Jury verdicts in Title IX retaliation claims have involved many times that amount in part because of the intentional conduct on the part of the defendants. Rather than merely reflecting on employees, these sizable jury verdicts reflect the economic tensions for women's athletics more broadly. As the current economic recession further delays plans to expand women's sports, the 
internal tensions for women in athletic departments are increased, and with it the potential for retaliation claims. There is little reason to believe that these types of lawsuits might decline absent some change of economic forces and perspective among some academic leaders.

\section{Presidents' Call for Transparency May Not Solve the Divide Between Football, Men's Basketball and All Other Sports}

A Sustainable Model reports that "nearly 8 in 10 presidents agree that greater transparency of athletics operating and capital costs is needed" (Perko \& Turner, 2010; emphasis on original.) Although transparency has been a key factor in solving many problems in intercollegiate athletics, it is questionable whether the same strategy is a solution to the intractable problems of the intercollegiate financial model facing athletics.

In the 1970s and 1980s, the failure of NCAA athletes to graduate or have meaningful access to a college education tore at the heart of the educational mission of athletics; cases like Ross v. Creighton University (1992) ${ }^{10}$ and Jackson v. Drake University (1991) appeared where academically unqualified students were admitted to play on Division I basketball teams. Often, athletes attended college for four years, exhausted their athletic eligibility, and left without being close to completing their degree. The stories created a public relations problem; an awareness of a possible pretext of the purported "educational mission of athletics." The stories of the athletes in litigation were not unique. In 2003, 13 colleges and universities with teams qualifying for the NCAA basketball tournament failed to graduate a single African-American student athlete (Lapchick, 2002). The impetus to change the status quo came from this sense of embarrassment, a desire to protect student athletes from potential exploitation, and the obvious conflict with the rest of the university's educational mission (Byers, 1995).

Transparency in student-athlete graduation rates has therefore been a major impetus for the overhaul to the academic requirements for NCAA athletes beginning in 2002 at the Institute for Diversity and Ethics in Sport. Changes have included heightened eligibility rules, including a number of core course requirements in high school. In 2004, the NCAA instituted a metric known as the Academic Progress Rate (APR). Points are awarded to determine whether each team member has remained academically eligible. Teams with an APR score that translates into less than approximately $60 \%$ graduation rate can be sanctioned with gradually increasing penalties, including losses of scholarships, recruiting, postseason competition, and ultimately to the loss of Division I status (NCAA bylaws, Article 14). While there are still some concerns, graduation rates for intercollegiate athletes have improved substantially with the APR (NCAA, 2008).

Contrasted with the exponential growth of intercollegiate athletic spending, A Sustainable Model reflects little of the same sense of embarrassment related to extreme spending. In fact, presidents of less competitive institutions that are not sharing in the bounty feel that their programs are being unfairly exploited (Perko \& Turner, 2010). They seek entre into this economic model, rather than a change in the fundamentals. Indeed, several presenters at the 2010 NCAA Scholarly Col- 
loquium in Atlanta made rational arguments in favor of current intercollegiate spending rates. ${ }^{11}$

To the contrary, some colleges and universities openly boast about spending, or at least seem to be unconcerned about its legal, educational, and economic ramifications. "We are the Jones"' proclaims the University of Texas, implying that escalated spending is defensible for its own sake, daring other schools to try to keep up. On a per-student-athlete basis, UT's athletics department spends \$244,684 a year for each of its 511 athlete-students, while expenditures for students generally are \$11,344 per student (Palaima \& Tublitz, 2009). To make an analogy, this type of big spending in athletics is like gloating about paying twenty times more for a car than its sticker price, at a time when subsidies to car purchasers have dropped precipitously, making cars unaffordable to those who need them for employment. Without the sense that wild spending increases are highly problematic on the same scale of failing to graduate athletes, transparency in institutional spending is therefore unlikely to produce the same sort of systemic change to the current economic model of athletics.

\section{Uncertain Source for Systemic Change Necessary To Reign In Runaway Spending In Athletics}

A Sustainable Model reveals that many presidents view a Sherman Antitrust Act exemption as a political impossibility (Perko \& Turner, 2010). In addition, the NCAA has fiercely defended itself against changes to the tax code that might make intercollegiate athletics reflect its asserted educational mission. (Brand, 2006; Colombo, 2009). Yet it is hard to imagine how intercollegiate athletics would look today if the dissents in just two antitrust decisions interpreting Section 1 of the Sherman Antitrust Act had been the majority opinions: NCAA v. Board of Regents of the University of Oklahoma (1984) and Law v. NCAA ${ }^{12}$ (1998; Schaefer, 2005). In Justice White's dissent in Board of Regents, he warned of the danger of not allowing the NCAA to tightly regulate intercollegiate athletics; that without it, collegiate athletics was in danger of becoming over-commercialized. After those two court decisions, the NCAA can no longer control football television revenues or distribute any revenues consistent with the educational goals of the entire NCAA membership. Those cases set the underlying economic model of unsound spending in collegiate athletics that is the root of the consequences addressed in A Sustainable Model. Competitive forces now compel outrageous expenditures that are unrelated to producing a better product or a better education. Instead, the current economic structure rewards winning athletic programs over other goals, academics and sustainability being just two (Zimbalist, 1990). Only through acting collectively can the economic model of intercollegiate athletics be changed to ensure that all sports - such as wrestling, swimming, tennis and track and field-will continue to exist on college and university campuses.

In the twenty-five years since the Supreme Court ruling, Justice White's clairvoyance is now accepted as the economic inevitable in collegiate athletics. Costs have spiraled, necessitating the 2009 Knight Commission survey of presidents, and the 2010 NCAA Scholarly Colloquium itself. Yet the economic model is amenable to change. Here, a federal statute such as the Sherman Antitrust Act has been judicially interpreted to be an impediment to educational progress (Schaefer, 2005). Tax laws 
for nonprofits have been interpreted to funnel runaway commercialized dollars away from educational pursuits (Colombo, 2009; Kretchmar, 2009; Mitten, Musselman, and Burton, 2009). A consortium of academics is required; empowered to enact meaningful reforms that both return the educational mission to collegiate sports and uproot the cancerous economic "arms race" that is destroying them. An empowered group with the political will and competence to change the status quo can effectuate the necessary changes. Who must be part of this is lacking. That source of change has yet to be identified, but A Sustainable Model makes it clear that it is not current presidents.

When colleges and universities want to protect themselves from certain taxes and avoid direct payments to athletes, they assert that college sports are an integral part of the educational mission of the college or university (Brand, 2006). Academics have proven the validity of the mission, such as the most recent compendium, Her Life Depends On It II; Sports, Physical Education and the Health and Well Being of Girls (Staurowsky et al., 2009). The report examines the relationship between participation in sport and physical activity on the health of girls and women, compiled from more than 2,000 studies. Contrary to the "dumb jock" myth, interscholastic sports participation provides both boys and girls from diverse socioeconomic, racial, and ethnic backgrounds measurable positive educational impacts, including improvements in self-concept, higher educational aspirations in the senior year, improved school attendance, increased math and science enrollment, more time spent on homework, and higher enrollment in honors courses (Marsh, 1993; Tucker Center for Research on Girls \& Women in Sport, 2007). For those aspiring to work in the sports industry, a common gateway is a significant sports participation experience on one's resume. The business of sports, including athletic administration, coaching, sports management, sports medicine, marketing and manufacturing, is a nearly \$200 billion per year industry (Plunkett Research Ltd. 2010).

Yet when women and men in Olympic sports demand equal access to, and an equal emphasis on, the educational benefits of athletics, colleges and universities defend their inequitable spending by pointing to market forces and the commercial nature of big-time college sports. It's an unfair double standard, and it is aptly demonstrated by the responses of presidents in A Sustainable Model.

These are not impossible problems to solve, only difficult problems. If presidents have either abdicated the responsibility for changing the economic model of intercollegiate athletics or see themselves as incapable to make the change in the face of vested interests, a new source for change must be identified and empowered. Perhaps former presidents with extensive NCAA experience, together with former athletic directors committed to the education sport model. Their positions are no longer in jeopardy and their experience could be crucial. Sports are a powerful part of education, and cost-containment efforts that return the educational focus to sports ought to be pursued, even if it means taking on difficult political battles. Financial stability consistent with the educational mission of athletics should not be an impossible goal.

\section{Notes}

1. Beyond the work of scholars, the data have had ample opportunity to percolate into the minds of the general public. E.g., Wolff, A., (1992, September 29) The Slow Track, Sports Illustrated. "How can football possibly pay for women's sports? Football can't even pay for itself. It grosses 
a lot of money but rarely makes any. In 1989 only about 13 percent of the NCAA's 524 football programs covered their expenses."

2. These numbers do not fully reflect the change in athletic expenses, because in 1993, expenses were further divided into three accounting categories instead of male/ female. The third category, "Administrative Expenses" currently stands at $\$ 12,900,000$, or over double the expenses allocated to women's sports. (Fulks, 2008).

3. This article refers to all men's sports except football and men's basketball as "Olympic Sports." Numerous commentators have criticized the term "non-revenue producing sports" since almost all sports generate some revenue, but very few generate a profit.

4. The Study refers "equity presidents" as those presidents from conferences whose winners receive automatic bids to the Bowl Championship Series ("BCS"). These include the ACC, Big Ten, Big XII, Pac-10, Big East, and SEC. Notre Dame is also included.

5. Federal administrative and legislative offenses against Title IX have been almost uninterrupted. See, e.g., The 2002 Commission on Opportunities in Athletics. Hogshead-Makar, N., (2004) Tilting the Playing Field: Schools, Sports, Sex and Title IX, UCLA Women's Law Journal 13, 101; Hogshead-Makar, N. \& Marburger, D., (2003). Is Title IX Really to Blame for the Decline in Intercollegiate Men's Non- Revenue Sports? Marquette Sports Law 14, 65. In addition, numerous legal challenges to the regulations interpreting Title IX have failed. Chalenor v. Univ. of N.D., 291 F.3d 1042, (8th Cir. 2002); Pederson v. La. State Univ., 213 F.3d 858 (5th Cir. 2000), Neal v. Bd. of Trs. Of Cal. State Univ., 198 F.3d 763 (9th Cir. 1999); Horner v. Ky. High Sch. Athletic Assn', 43 F.3d 265 (6th Cir. 1994); appeal after remand, 206 F3d 685 (6th Cir. 2000), cert denied, 531 U.S. 824 (2000); Kelly v. Bd. of Trs., Univ. of Ill., 35 F.3d 265 (7th Cir. 1994), cert denied, 513 U.S. 1128 (1995); Cohen v. Brown Univ., 991 F2d 888 (1st Cir. 1993); Cohen v. Brown Univ., 101 F3d 155 (1st Cir 1996), cert. denied; Roberts v. Colo State Bd of Agric., 998 F2d 824 (10th Cir. 1993), cert denied 510 U.S. 1004 (1993); Williams v. Sch. Dist. Of Bethlehem, 998 F. 2d 168 (3d Cir. 1993), cert. denied, 510 U.S. 1043 (1994); Nat'l Wrestling Coaches Ass'n v. U.S. Dep't of Educ., 263 F. Supp. 2d 82 (D.D.C. 2003), aff'd 366 F.3d 930 (D.C. Cir. 2004), cert. denied, 545 U.S. 1104 (2005).

6. The award, named in recognition of former President Gerald Ford, honors individuals who have provided significant leadership as an advocate for higher education and intercollegiate athletics on a continuous basis over the course of his or her career.

7. Recently, the United States Supreme Court held in a unanimous opinion that Title IX and the Fourteenth Amendment were coextensive. Fitzgerald v. Barnstable School Committee, 555 U. S. (2009). (a claim filed under Title does not preclude the use of 42 U.S.C. Section 1983 to further constitutional claims, when Title IX was not meant to be the exclusive tool for addressing gender discrimination in schools, or a substitute for actions filed under Section 1983 to enforce constitutional rights.) For public schools, changes to gender equity legislation or to the regulations interpreting Title IX would have little effect. The Fourteenth Amendment still requires state actors to provide equal educational opportunities, including sports. See e.g., Hoover v. Meiklejohn, 430 F. Supp. 164 (D. Colo. 1977), (Colorado High School Activity Association's policy of limiting soccer participation to males violated Equal Protection); Blair v. Washington State University, 740 P. 2d 1379 (Wash 1987); Mularadelis v. Haldane Central School Board, 74 A.D. 2d 248 (N.Y. App. Div. 1980); Clark v. Arizona Interscholastic Association, 695 F. 2d 1126 (Ariz. 1982); B.C. v. Board of Education, Cumberland Regional School District, 531 A. 2 d 1059 (N.J. Super. 1987; applying Equal Protection analysis to athletics).

8. While Florida High School football brought revenues to the FHSAA from a percentage of the gate from gross revenues, the sport did not generate revenues for school districts, who were paying for items such as coaches' pay and security. See Palka, M., (2009, July) High school football makes money, but not enough. Even the most popular sport, football, often comes up budget short, Jacksonville Times Union. 
9. Other Membership Bylaws do not address the Athletics Department as a whole. For example, NCAA Bylaw 20.9.7.3 requires members to average at least 15,000 in actual or paid attendance for all home football contests over a rolling two-year period, and Bylaw 20.9.7.4-(a) requires members to provide an average of at least ninety percent of the permissible maximum number of overall football grants-in-aid per year over a rolling two-year period.

10. Creighton University accepted Kevin Ross, allegedly assuring Mr. Ross he would receive a meaningful education while at Creighton. After his basketball eligibility was expended, he had a D average, many of his courses did not count toward the completion of his degree, and he alleged that a secretary read his assignments and prepared and typed his papers. After leaving Creighton, Mr. Ross has overall language skills of a fourth grader and the reading skills of a seventh grader. His educational malpractice claim was dismissed, but the court upheld his contractual claim on the limited question of whether he was barred from any participation in and benefit from the University's academic program.

11. Many did not consider the gender implications in the skewed gender financial distribution.

12. While other antitrust lawsuits have been filed against the NCAA, Law and Board of Regents have had the biggest impact.

\section{References}

Acosta, R., \& Carpenter, L. (2008). Women in intercollegiate sport: a longitudinal, national study: thirty-one year update, 1977-2010. Retrieved on June 15, 2010, from http:// www.acostacarpenter.org/.

B.C. v. Board of Education, Cumberland Regional School District, 531 A. 2d 1059 (N.J. Super. 1987).

Barnett, C. (2009, December 1). It's rough and tumble at FHSAA. Florida Trend Magazine, 60-64. Retrieved February 3, 2010, from http://www.floridatrend.com/article. asp?aID=52077.

Blair v. Washington State University, 740 P. 2d 1379 (Wash 1987).

Brand, M. (2006, November 13) (Letter to Representative Bill Thomas, Chairman, House Committee on Ways and Means.

Byers, W. (1995). Unsportsmanlike conduct—exploiting college athletes. Ann Arbor: University of Michigan Press.

Chalenor v. University of North Dakota, 291 F.3d 1042, ( $8^{\text {th }}$ Cir. 2002).

Cheslock, J. (2008). Who's playing college sports? Money, race and gender. East Meadow, N.Y.: Women's Sports Foundation.

Clark v. Arizona Interscholastic Association, 695 F. 2d 1126 (Ariz. 1982).

Cohen v. Brown University, $991 \mathrm{~F} 2 \mathrm{~d} 888$ ( $1^{\text {st }}$ Cir. 1993).

Cohen v. Brown University, $101 \mathrm{~F} 3 \mathrm{~d} 155$ ( $1^{\text {st }}$ Cir 1996).

Colombo, J. (2009). The NCAA, tax exemption and college athletics. Journal of Intercollegiate Sport, 2, 318-320.

Fitzgerald v. Barnstable School Committee, 555 U. S. (2009).

Florida High School Athletic Association. (http://www.fhsaa.org/forms/pdf/titleix.pdf).

Fulks, D. (2002). Revenues and expenses of Division I and II intercollegiate athletic programs: financial trends and relationships 2001. Indianapolis: NCAA.

Fulks, D. (2008). NCAA 2004-06: NCAA revenues and expenses of Division I intercollegiate athletics programs. Indianapolis: NCAA.

Gosselar, P., Lincoln, T., \& Arkush, D. (2009). The 6 percent bogeyman. Public Citizen. Retrieved February 3, 2010, from http://www.citizen.org/documents/NPDB_ Report_200907.pdf.

Hackney, H. (2009, November 20). Gender equity advocates hail settlement agreement in Cook v. FHSAA. Sports Litigation Alert 6. Retrieved February 3, 2010, from http:// www.sportslitigationalert.com/archive/2009_11_20.php. 
Hogshead-Makar, N. (2004). Tilting the Playing Field: Schools, Sports, Sex and Title IX. UCLA Women's Law Journal, 13, 101.

Hogshead-Makar, N., \& Marburger, D. (2003). Is Title IX Really to Blame for the Decline in Intercollegiate Men's Non- Revenue Sports? Marquette Sports Law, 14, 65.

Hogshead-Makar, N., \& Zimbalist, A. (2007). Equal play: Title IX and social policy. Philadelphia: Temple University Press.

Hoover v. Meiklejohn, 430 F. Supp. 164 (D. Colo. 1977).

Horner v. Kentucky High School Athletic Association, 43 F.3d 265 (6 ${ }^{\text {th }}$ Cir. 1994); appeal after remand, 206 F3d 685 (6 ${ }^{\text {th }}$ Cir. 2000), cert denied, 531 U.S. 824 (2000).

How \$194.64 billion is spent on sports. Street \& Smith's SportsBusiness Journal, 4, 47. Retrieved on February 3, 2010, from http://www.sportsbusinessjournal.com/images/ random/SportsIndustry.pdf.

Jackson v. Birmingham, 544 U.S. 167 (2005).

Jackson v. Drake University, 778 F.Supp. 1490 (S.D. Iowa 1991).

Kelly v. Board of Trustees, University of Illinois, 35 F.3d 265 ( $7^{\text {th }}$ Cir. 1994), cert denied, 513 U.S. 1128 (1995).

Kelso, J., \& Kelso, K. (1999). Jury verdicts in medical malpractice Cases and the MICRA cap. University of the Pacific, McGeorge School of Law. Retrieved on February 3, 2010, from http://www.mcgeorge.edu/x1234.xml.

Knight Foundation. (1991). Keep faith with the college athlete: a new model for intercollegiate athletics. Reports of the Knight Commission on Intercollegiate Athletics, 16-14. Retrieved February 3, 2010, from http://knightcommission.org/images/pdfs/1991- 93 KCIA_report.pdf.

Kretchmar, S. (2009). Assessment of Colombo's education argument. Journal of Intercollegiate Sport, 2, 184-201.

Law v. NCAA, 134 F. $3^{\text {rd }} 1010$ (10 $0^{\text {th }}$ Cir. 1998) cert. denied, 525 U.S. 822 (1988).

Lapchick, R. (2002). Institute for Diversity and Ethics in Sport. (2002). Keeping score when it counts: graduation rates for 2002-03 bowl-bound college football teams. Orlando: University of Central Florida. Retrieved on February 3, 2010, from Tidesport website, http://www.tidesport.org/Grad\%20Rates/2002-2003_Football_Bowl_Grad_Rates.pdf.

Lapchick, R. (2003, March 24). Study reveals some Sweet 16's men's teams fail to make the grade. Orlando: Institute for Diversity and Ethics in Sport, University of Central Florida. Retrieved on February 3, 2010, from Tidesport website, http://www.tidesport. org/Grad\%20Rates/2003_Men's_BB_Grad_Rates.pdf.

Lange, C. (2008). A matter of balance: work and life in intercollegiate athletics. Indianapolis: NCAA.

Marsh, H. (1993). The effects of participation in sport during the last two years of high school. Sociology of Sport Journal, 10, 18-43.

Mellman Group. (2007, June 14). Public opinion poll on Title IX. National Women's Law Center. Retrieved on February 3, 2010, from http://www.nwlc.org/pdf/ Memorandum\%20to\%20Interested \%20Parties\%20from\%20The\%20Mellman $\% 20$ Group\%2006\%2019\%2007.pdf.

Mitten, M., Musselman, J., \& Burton, B. (2009). Commercialized intercollegiate athletics: a proposal for targeted reform consistent with American cultural forces and marketplace realities. Journal of Intercollegiate Sport, 2, 202-232.

Mularadelis v. Haldane Central School Board, 74 A.D. 2d 248 (N.Y. App. Div. 1980).

National Wrestling Coaches Association v. U.S. Department of Education, 263 F. Supp. $2 \mathrm{~d} 82$ (D.D.C. 2003), aff'd 366 F.3d 930 (D.C. Cir. 2004), cert. denied, 545 U.S. 1104 (2005).

NCAA (2009) Bylaws, Article 14. Eligibility: academic and general requirements.

NCAA. (2007, March 1). Football bowl subdivision-membership requirements. Retrieved February 3, 2010, from http://www.ncaa.org/wps/wcm/connect/b96a1b004e0d521d9a 00fa1 ad6fc8b25/Footballqa .pdf?MOD=AJPERES\&CACHEID=b96a1b004e0d521d $9 \mathrm{a} 00 \mathrm{fa} 1 \mathrm{ad} 6 \mathrm{fc} 8 \mathrm{~b} 25$. 
NCAA. (2008). APR reports by school. Retrieved on February 3, 2010, from http://www. ncaa.org/wps/portal/ncaahome?WCM_GLOBAL_CONTEXT=/wps/wcm/co nnect/ ncaa/NCAA/Academics+and+Athletes/Education+and+Research/Academic+Refor m/ APR/2006-07_School_APR_Data_J51t9A.html.

NCAA v. Board of Regents of the University of Oklahoma, 468 U.S. 85 (1984).

Neal v. Board of Trustees of California State University, 198 F.3d 763 (9 $9^{\text {th }}$ Cir. 1999).

Orszag \& Orszag, (2005).The Empirical Effects of Collegiate Athletics: An Update, Compass for the NCAA, April 2005.

Palaima, T., \& Tublitz, N. (2009, January 9). Barack Obama and the international education bowl. Inside Higher Ed. Retrieved on February 3, 2010, from http://www.insidehighered. com/layout/set/print/views/2009/01/09/palaima.

Palka, M. (2009, July 13). High school football makes money, but not enough. Florida Times-Union. Retrieved February 3, 2010, from http://jacksonville.com/news/ metro/2009-07-13/story/high_school_football_makes_money_but_not_enough.

Pederson v. Louisiana State University, 213 F.3d 858 ( $5^{\text {th }}$ Cir. 2000).

Perko, A., \& Turner, G. (2010). A sustainable model? University assess the costs and financing of intercollegiate athletics. NCAA scholarly colloquium: college sports in recessionary times. Atlanta: NCAA.

Powers, E. (2007, January 27). A Knight Commission Roundtable. Inside Higher Ed. Retrieved on February 3, 2010, from http://www.insidehighered.com/news/2007/01/23/ knight.

Public Justice Foundation. (2008, October 15). Former head coaches, FGCU reach landmark settlement in case charging retaliation and defamation over Title IX violations. Retrieved on February 3, 2010, from http://www.publicjustice.net/Repository/Files/NR\%20-\%20 Flood\%20and\%20Vaughn\%20Settlement\%20-\%20Oct\%2008.pdf.

Roberts v. Colorado State Board of Agriculture, 998 F2d 824 (10 ${ }^{\text {th }}$ Cir. 1993), cert denied 510 U.S. 1004 (1993).

Ross v. Creighton University, 957 F.2 $2^{\text {nd }} 410$ ( $7^{\text {th }}$ Cir., Ill. 1992).

Schaefer, A. (2005). Slam dunk: the case for an NCAA antitrust exemption. North Carolina Law Review, 83, 555-568.

Staurowsky, E.J., DeSousa, M.J., Ducher, G., Gentner, N., Miller, K.E., Shakib, S., et al. (2009). Her Life Depends On It II: Sport, Physical Activity, and the Health and WellBeing of American Girls and Women. East Meadow, NY: Women's Sports Foundation.

Steeg, J. (2008, May 13). Lawsuits, disputes reflecting continuing tensions over Title IX. USA Today. Retrieves on February 3, 2010, from http:/www.usatoday.com/sports/ college/2008-05-12-titleix-cover_N.htm.

Steeg, J. (2008, May 12). Timeline of gender equity issues at Fresno State. USA Today. Retrieved on February 3, 2010, from http://www.usatoday.com/sports/college/ 2008-05-12-fresno-timeline_N.htm.

Thomas, K. (2009, July 15). Florida drops budget plan that favored prep football. New York Times. Retrieved February 3, 2010, from http://www.nytimes.com/2009/07/16/ sports/16football.html.

Title IX of the Education Amendments of 1972. Title IX, 20 U.S.C. §§ 1681-1688 (2006).

United States Department of Justice Amicus Brief in. Cook v. FHSAA. (http://www.justice. gov/crt/edo/documents/fhsaabrief.pdf).

U.S. Const. amend XIV.

Williams v. School District Of Bethlehem, 998 F. 2d 168 (3d Cir. 1993), cert. denied, 510 U.S. 1043 (1994).

Wolf, A. (1992, September 28). The slow track. Sports Illustrated, 52-64.

Zimbalist, A. (1990). Unpaid professionals: commercialism and conflict between big-time college sports. Princeton: Princeton University Press. 